\title{
Implemensi Literasi Sains dalam Pembelajaran IPA di Sekolah Dasar
}

\author{
Irsan \\ Pendidikan Guru Sekolah Dasar, Universitas Muhammadiyah Buton, Indonesia \\ E-mail: irsanlely@gmail.com
}

\begin{abstract}
Abstrak
Dalam pembelajaran IPA, literasi sains memiliki peranan yang sangat penting karena mempersiapkan peserta didik yang berkualitas, handal, dan mampu berkompetisi dengan dunia internasional. Untuk dapat menciptakan dan mengembangkan literasi sains dalam pembelajaran IPA, guru perlu menciptakan kondisi belajar yang melibatkan keaktifan peserta didik. Pembelajaran yang hanya didominasi oleh guru melalui metode ceramah dan buku ajar, hanya mengakibatkan peserta didik menjadi pendengar yang pasif dan menimbulkan kejenuhan bagi peserta didik. Kejenuhan inilah yang nantinya akan membuat peserta didik tidak memiliki penalaran dan pengetahuan tentang literasi sains. Adapun tujuan dari penelitian ini adalah untuk mengetahui implementasiliterasi sains dalam pembelajaran IPA di sekolah dasar. Metode yang yang digunakan dalam penelitian ini adalah literature review/studi literatur dan observasi lapangan dan wawancara. Data diperoleh dari mentelaah artikel, jurnal maupun sumber-sumber yang lain yang berkaitan dengan penelitian dan juga melalui observasi kemudian disimpulkan. Pengolahan dan analisis data dilakukan secara kualitatif dengan penjabaran deskriptif. Diketahui hasil penelitian ini yaitu Implementasi literasi sains dapat mengembangkan pola pikir dan prilaku siswa serta membangun karakter manusia untuk peduli, bertanggungjawab terhadap dirinya, masyarakat, alam semesta serta terhadap masalah yang dihadapi masyarakat modern saat ini. Siswa yang mampu mengembangkan literasi sains dapat membuat keputusan yang mendasar dan mampu mengenali sumber solusi yaitu sains dan teknologi. Literasi sains juga memiliki peranan yang penting untuk membangun kesejahteraan masyarakat dimasa sekarang maupun masa yang akan datang.
\end{abstract}

Kata Kunci: Literasi Sains, IPA, Sekolah Dasar.

\begin{abstract}
In science learning, scientific literacy has a very important role because it prepares students who are qualified, reliable, and able to compete with the international world. To be able to create and develop scientific literacy in science learning, teachers need to create learning conditions that involve the activeness of students. Learning which is only dominated by the teacher through the lecture method and textbooks, only causes students to become passive listeners and causes boredom for students. This saturation will make students not have reasoning and knowledge about scientific literacy. The purpose of this study was to determine the implementation of scientific literacy in science learning in elementary schools. The method used in this research is a literature review/literature study and field observations and interviews. Data obtained from reviewing articles, journals and other sources related to research and also through observation and then concluded. Data processing and analysis was carried out qualitatively with descriptive elaboration. It is known that the results of this study are that the implementation of scientific literacy can develop the mindset and behavior of students and build human character to care, be responsible for themselves, society, the universe and the problems faced by modern society today. Students who are able to develop scientific literacy can make basic decisions and are able to identify sources of solutions, namely science and technology. Scientific literacy also has an important role in building the welfare of society now and in the future.
\end{abstract}

Keywords: Science Literacy, Science, Elementary School.

Copyright (c) 2021 Irsan

Corresponding author :

Email : irsanlely@gmail.com

DOI : https://doi.org/10.31004/basicedu.v5i6.1682

ISSN 2580-3735 (Media Cetak)

ISSN 2580-1147 (Media Online) 


\section{PENDAHULUAN}

Era Digital saat ini mengalami perkembangan yang sangat pesat khusunya Ilmu pengetahuan dan teknologi (IPTEK) Hal ini berdampak pada perkembangan pendidikan yang ada di Indonesia saat ini. Pesatnya perkembangan sains mengharuskan manusia untuk bekerja menyesuaikan pada berbagai aspek kehidupan. Dalam mewujudkan Pendidikan yang semakin maju harus didukung oleh sumber daya manusia (SDM) Salah satu untuk menyikapinya adalah dengan sience literasy.

Di abad ke-21 sekarang literasi sains diduga bagaikan pokok pada pendidikan, sebab kemampuan sains serta teknologi sebagai pokok kesuksesan warga negara ( Asrizal et al., 2017). Kemampuan literasi sains adalah keahlian yang harus diciptakan untuk menghadapi globalisasi, karena membuat peserta didik tidak hanya sekedar untuk melihat, tetapi juga dapat dengan sesuai menerapkan ide-ide sains pada aktivitas seharihari mereka (Rizkita, L., Suwono, H., \& Susilo, 2016). Sejalan dengan itu OECD berpendapat bahwa mencirikan literasi sains sebagai berikut (1) informasi logis individu dan kapasitas untuk memanfaatkan informasi tersebut untuk membedakan masalah, mendapatkan informasi baru, memperjelas keajaiban logis, dan mencapai keputusan berlandaskan kebenaran yang diidentifikasi dengan masalah logis; (2) mengetahui kualitas pertama informasi yang bekerja dari permintaan manusia; (3) peka terhadap bagaimana sains dan inovasi membentuk materi, iklim ilmiah dan sosial; (4) kemampuan untuk dikaitkan dengan masalah dan pemikiran yang diidentifikasikan dengan sains. Sehingga kemampuan logika adalah suatu harapan yang mesti diperoleh dalam mata pelajaran yang diidentikkan dengan sains.

Literasi sains dapat diartikan sebagai suatu kemampuan seseorang dalam memahami sains, mengkomunikasikan sains dan menerapkan pengetahuan sains yang dimiliki untuk memecahkan masalah, sehingga dapat meningkatkan sikap dan kepekaan terhadap lingkungan sekitar. Penguasaaan dan kemampuan pemahaman sains dan teknologi di era digital ini menjadi peranan penting keberhasilan pendididikan suatu bangsa. Pada Pembelajaran IPA atau sains sebagai salah satu bagian dari Pendidikan memiliki peran penting dalam menghasilkan dan membentuk peserta didik yang memiliki kemampuan berpikir kritis, logis, kreatif, inovatif, dan berdaya saing global. Pembelajaran sains juga diharapkan menhjadi fondasi utama Pendidikan sebagai wahana bagi peserta didik untuk lebih mengenal sains secara kontekstual dan mengimplementasikan dalam kehidupan sehari-hari. Sehingga literasi sains menjadi suatu hal yang wajib bagi tiap peserta didik. Sebagaimana yang dikemukakan bahwa Ilmu Pengetahuan Alam (IPA) adalah salah satu cara manusia yang mencakup aktivitas psikologis, pengetahuan, serta cara mengatur maupun mengukur, yang bisa dicoba lagi keabsahannya didasarkan oleh perilaku kuriositas, ketetapan hati, kegigihan yang dilaksanakan oleh perseorangan untuk mendekap rahasia jagat raya. Natural science deals with how to logically find out about the universe, so that science is not just a group domination of understanding in the form of fact, theories, and grounds, but also ways of discovery (van Noordwijk, 2021). Kegiatan belajar mengajar sains memusatkan dalam pembagian profesionalisme secara nyata pada peserta didik tentang potensi pengembangan, memungkinkan siswa untuk memahami lingkungan alam melalui proses penemuan, yang akan membantu siswa memperoleh pengalaman tentang lingkungan alam. Namun dalam suatu pandemi, studi sains harus diselesaikan secara online atau mandiri oleh siswa (Handayani \& Jumadi, 2021)

Dalam pembelajaran IPA, literasi sains memiliki peranan yang sangat penting karena mempersiapkan peserta didik yang berkualitas, handal, dan mampu berkompetisi dengan dunia internasional. Untuk dapat menciptakan dan mengembangkan literasi sains dalam pembelajaran IPA, guru perlu menciptakan kondisi belajar yang melibatkan keaktifan peserta didik. Pembelajaran yang hanya didominasi oleh guru melalui metode ceramah dan buku ajar, hanya mengakibatkan peserta didik menjadi pendengar yang pasif dan menimbulkan kejenuhan bagi peserta didik. Kejenuhan inilah yang nantinya akan membuat peserta didik tidak memiliki penalaran dan pengetahuan tentang literasi sains.

Penekanan literasi sains bukan hanya pada aspek pengetahuan dan pemahaman terhadap konsep dan proses sains saja, namun juga diarahkan pada proses seseorang dalam membuat keputusan dan berpartisipasi 
dalam kehidupan bermasyarakat. Literasi sains di abad ini tidak lagi hanya penggunaan sains dan teknologi dalam memahami alam semesta. Namun, literasi sains memiliki tingkatan, dari literasi sains terendah yang disebut literasi sains praktis yang merujuk pada kemampuan seseorang dalam kehidupan sehari-hari, sebagai konsumen dari produk sains dan teknologi. Hal ini berhubungan dengan kebutuhan dasar manusia yaitu makan, kesehatan dan rumah atau tempat tinggal. Literasi sains tingkat tinggi, seperti literasi kewarganegaraan yang mengacu pada keterampilan seseorang untuk berpartisipasi dalam mengambil keputusan dan mengggunakannya secara bijak, terkait isu politik, ekonomi, sosial, budaya dan kenegaraan.

Berdasarkan hasil survei PISA tahun 2000 sampai tahun 2018, Indonesia sebagai salah satu Negara dengan literasi sains yang rendah. Hasil PISA untuk peserta didik Indonesia pada tahun 2015 saja masih beraa dibawah rata-rata nilai sains Negara OECED. Rata-rata nilai sains untuk domain literasi sains pada Negara OECED yaitu 493, sedangkan Indonesia baru mencapai skor 403. Hal ini menunjukkan bahwa terdapat kesenjangan dalam memperlakukan pendidikan IPA. Pada sistem pendidikan nasional, literasi sains mulai diakomodasikan dalam kurikulum yaitu Kurikulum Tingkat Satuan Pendidikan (KTSP) dan Kurikulum 2013. Pada kurikulum 2013 melalui pendekatan sainstifik, dimana pembelajaran yang berpusat pada peserta didik dan menekankan pada proses inkuiri melalui tahapan pendekatan sainstifik. Oleh karena itu, penerapan literasi sains dalam pendidikan sangatlah diperlukan, lebih khusus dalam pembelajaran sains (Rustaman, 2017).

Rendahnya hasil belajar sains yang diperoleh peserta didik tentunya berhubungan dengan proses pembelajaran sains yang belum memberikan peluang bagi peserta didik untuk mengembangkan kemampuan berpikir kritis. Pembelajaran sains yang masih bersifat menghafal belum mampu menunjukkan aspek sains sebagai pembelajaran yang sesuai dengan hakikat sains menurut (Fadillah, 2017)yaitu sains sebagai cara berpikir, sains sebagai cara menyedili, sains sebagai tubuh pengetahuan, sains dan interaksinya dengan teknologi dan masyarakat.

Ada beberapa hal pokok dalam mengembangkan literasi sains peserta didik yaitu pengetahuan tentang sains, proses sains, pengembangan sikap ilmiah dan pemahaman peserta didik terhada sains. Berdasarkan hal pokok tersebut diharapkan, peserta didik dapat menerapkan pengetahuan yang diperoleh di sekolah untuk diterapkan dalam memecahkan permasalahan yang ada dalam kehidupan sehari-hari. Tujuan seorang pendidik mengembangkan literasi sains peserta didiknya untuk meningkatkan (Pertiwi et al., 2018), 1) pengetahuan dan penyelidikan Ilmu Pengetahuan Alam 2) kosa kata lisan dan tertulis yang diperlukan untuk memahami dan berkomunikasi ilmu pengetahuan dan 3) hubungan antara sains, teknologi, dan masyarakat. Dalam mengembangkan literasi sains siswa, guru ditantang untuk memadukan model pembelajaran dan kemajuan teknologi informasi untuk mengimbangi gaya belajar siswa yang beragam.

Oleh karena itu, dengan adanya literasi sains dalam pembelajaran, siswa-siswi diharapkan memiliki kemampuan yang harus dimiliki yaitu: a) memiliki kemampuan pengetahuan dan pemahaman tentang konsep ilmiah dan proses yang diperlukan untuk berpartisipasi dalam masyarakat di era digital, b) kemampuan mencari atau menentukan jawaban pertanyaan yang berasal dari rasa ingin tahu yang berhubungan dengan pengalaman sehari-hari, c) memiliki kemampuan, menjelaskan dan memprediksi fenomena. d) dapat melakukan percakapan sosial yang melibatkan kemampuan dalam membaca dalam mengerti artikel tentang Ilmu pengetahuan; e) dapat mengindentifikasi masalah-masalah ilmiah dan teknologi informasi; f) memiliki kemampuan dalam mengevaluasi informasi ilmiah atas dasar sumber dan metode yang dipergunakan; g) dapat menarik kesimpulan dan argument serta memiliki kapasitas mengevaluasi argument berdasarkan bukti. Untuk mengukur tingkat kemampuan literasi sain, diperlukan penilaian literasi sains tersebut.

Secara harfiah, literasi sains terdiri dari kata yaitu literatus yang berarti melek huruf dan scientia yang diartikan memiliki pengetahuan. Literasi sains dapat diartikan sebagai pengetahuan dan kecakapan ilmiah untuk mampu mengidentifikasi pertanyaan, memperoleh pengetahuan baru, menjelaskan fenomena ilmiah, serta mengambil simpulan berdasar fakta, memahami karakteristik sains, kesadaran bagaimana sains dan teknologi membentuk lingkungan alam, intelektual, dan budaya, serta kemauan untuk terlibat dan peduli terhadap isu-isu yang terkait sains(Narut \& Supradi, 2019). (Kristyowati \& Purwanto, 2019)menyatakan 
bahwa rangkaian kompetensi ilmiah yang dibutuhkan pada literasi sains mencerminkan pandangan bahwa sains adalah ansambel dari praktik sosial dan epistemik yang umum pada semua ilmu pengetahuan, yang membingkai semua kompetensi sebagai tindakan.

Literasi sains menurut PISA diartikan sebagai "the capacity to use scientific knowledge, to identify questions and to draw evidence-based conclusions in order to understand and help make decisions about the natural world and the changes made to it through human activity". (Zuriyani, 2021), literasi sains adalah suatu ilmu pengetahuan dan pemahaman mengenai konsep dan proses sains yang akan memungkinkan seseorang untuk membuat suatu keputusan dengan pengetahuan yang dimilikinya, serta terlibat dalam hal kenegaraan, budaya, dan pertumbuhan ekonomi. (Fitariya, 2018) menyebutkan bahwa literasi sains merupakan tujuan akhir dari pendidikan sains dengan kata lain pembelajaran sains diberikan kepada peserta didik dengan tujuan untuk membentuk peserta didik yang berliterasi sains.

Literasi sains merupakan kemampuan menggunakan pengetahuan sains, mengidentifikasi pertanyaan, dan menarik kesimpulan berdasarkan bukti-bukti yang ada dalam rangka memahami serta membuat keputusan berkenaan dengan alam dan perubahan yang dilakukan terhadap alam melalui aktivitas manusia. Noris dan Phillip dalam (Cahyani \& Roviati, 2016) literasi sains digunakan utuk berbagai aspek yang meliputi pengetahuan mengenai konten substanf sains, pemahaman sains dan penerapannya, pengetahuan mengenai sains, kebebasan dalam belajar sains, kemampuan berpikir ilmiah, kemampuan menggunakan pengetahuan sains dalam memecahkan masalah, berpartisipasi cerdas dalam isu- isu sains, sifat-sifat sains, penghargaan sains, dampak dan manfaat sains serta kemampuan berpikir kritis. Literasi sains menurut (Basam et al., 2016) adalah kemampuan menggunakan pengetahuan, mengidentifikasi pertanyaan, dan menarik kesimpulan berdasarkan bukti-bukti dalam rangka memahami serta membuat keputusan berkenaan dengan alam dan perubahan yang dilakukan terhadap alam melalui aktivitas manusia.

Berdasarkan beberapa pendapat di atas dapat disimpulkan bahwa literasi sains adalah suatu kemampuan, kecakapan, kompetensi yang dimiliki oleh peserta didik dengan pengetahuan dan pemahaman mengenai konsep dan proses sains untuk mengidentifikasi, memperoleh pengetahuan baru, menjelaskan fenomena ilmiah, serta mengambil simpulan yang berkenaan dengan alam berdasarkan perubahan alam melalui aktivitas manusia.

Walaupun pembelajaran literasi sains berkembang mengikuti arah perkembangan keilmuan dan interaksi sosial, maka pembelajaran sains berbasis literasi tidak mudah untuk dilakukan. (Syofyan \& Amir, 2019) mengemukakan beberapa permasalahan umum dalam pembeajaran sains yang berkaitan dengan rendahnya kemampuan literasi sains, khususnya di tingkat indikator dasar dan menengah. Salah satu indikator ketidaksukaan yang ditunjukkan oleh peserta didik yakni kurangnya keterkaitan antara konten atau materi yang dibelajarkan, dengan hal-hal yang terjadi dalam kehidupan sehari-hari. Sejalan dengan kondisi tersebut, guru di masa depan akan mendapat tantangan besar dalam penyelenggaraan Indikator global dan berkualitas. Guru harus meningkatkan literasi sains agar dapat membawa peserta didik untuk berorientasi kepada konstruksi makna, pembelajaran aktif, akuntabilitas, penggunaan teknologi, peningkatan kompetensi siswa, kepastian pilihan dan bermasyarakat multikultur (Syofyan \& Amir, 2019).

Literasi sains penting untuk dimiliki siswa karena alasan berikut: 1) pemahaman sains menawarkan pemenuhan kebutuhan personal dan kegembiraan, dapat dibagikan dengan siapa pun dan 2) negara- negara di dunia dihadapkan pada pertanyaan- pertanyaan dalam kehidupannya yang memerlukan informasi ilmiah dan cara berpikir ilmiah untuk mengambil keputusan dan kepentingan orang banyak yang perlu di informasikan seperti, udara, air dan hutan. Pemahaman sains dan kemampuan dalam sains juga akan meningkatkan kapasitas siswa untuk memegang pekerjaan penting dan produktif di masa depan. Kepemilikan literasi sains sangat penting, maka menjadi penting pula membangun literasi sains siswa sejak dini, selaku generasi penerus di masa depan. Salah satu upaya untuk itu dapat dilakukan dengan menciptakan pembelajaran sains yang mendukung terciptanya sumber daya manusia yang melek sains. Pemahaman IPA dan kemampuan dalam IPA juga akan meningkatankan kapasitas siswa untuk memegang pekerjaan penting dan produktif di masa depan. 
Masyarakat bisnis memerlukan pekerja pemula yang siap (Setiawan, 2019). Kemampuan literasi sains merupakan kemampuan dasar yang harus dimiliki oleh peserta didik, terutama dalam pembelajaran sains. Kemampuan literasi sains peserta didik dapat dikembangkan melalui pembelajaran yang berorientasi pada peserta didik, sehingga peserta didik mampu mengaplikasikan konsep sains yang telah dipelajari dalam menyelaikan permasalahan yang dihadapi di kehidupan sehari-hari.

Pada tingkat sekolah dasar, pembelajaran IPA atau sains merupakan salah satu pembelajaran yang menduduki peranan yang sangat penting karena sains dapat memberikan bekal peserta didik dalam menghadapi kemajuan ilmu pengetahuan dan teknologi dalam era digital. Oleh sebab itu, pembelajaran IPA yang ada di sekolah-sekolah diharapkan mampu menerapkan atau mengimplementasikan literasi sains dalam pembelajaran. Pembelajaran di sekolah melalui pembelajaran IPA diharapkan dapat mengembangkan kemampuan peserta didik dalam menghadapi kemajuan IPTEK melalui pembelajaran literasi sains.

\section{METODE}

Jenis penelitian ini adalah penelitian kualitatif deskriptif. Adapun metode yang digunakan dalam penelitian ini adalah literature review/studi literatur dan observasi lapangan dan wawancara. Data diperoleh dari mentelaah artikel, jurnal maupun sumber- sumber yang lain yang berkaitan dengan penelitian dan juga melalui observasi kemudian disimpulkan. Pengolahan dan analisis data dilakukan secara kualitatif dengan penjabaran deskriptif. Penelitian kepustakaan adalah riset yang dilaksanakan sama priset melalui sistem pengumpulan jumlah artikulasi yang berhubungan dengan hambatan serta harapan riset. Cara ini bermaksud untuk mengungkap beragam konsep yang berhubungan dengan hasil yang sedang dibahas sebagai bahan referensi. Penelitian literatur adalah fase terpenting dari semua jenis penelitian. Sumber dalam riset ini mengutip dari buku, jurnal, serta penelitian yang telah selesai. Studi tinjauan literature merupakan jenis riset ini, yang tujuannya untuk mengidentifikasi terkait implementasi literasi sains pada pemblajaran IPA di Sekolah Dasar.

\section{HASIL DAN PEMBAHASAN}

\section{Implementasi Literasi Sains dalam Pembelajaran IPA di Sekolah Dasar}

Mengimplementasikan literasi sains dalam pembelajaran IPA di Sekolah Dasar siswa diharapkan memiliki kemampuan dalam hal pengetahuan dan pemahaman tentang konsep-konsep ilmiah dan proses yang diperlukan untuk partisipasi dalam masyarakat di era digital dan siswa juga diharapkan mampu mengidentifikasi serta mengatasi segala problematika yang ditemui siswa dalam pembelajaran di kehidupan sehari-hari. Dengan adanya literasi sains, siswa diharapkan mampu memenuhi berbagai tuntutan zaman yaitu dengan menjadi problem solver (pemecah masalah) dengan pribadi yang kompetitif, inovatif, kreatif, kolaboratif serta berkarakter sesuai dengan perkembangan kompetensi abad 21.

Literasi sains merupakan bagian terpenting dalam penentuan ketercapaian penguasaan Pendidikan IPA di Sekolah Dasar. Tentunya harus diiringi dengan proses pembelajaran yang interaktif, inspratif, menyengkan, menentang, dan dapat memotivasi siswa untuk berpartisipasi aktif dalam proses belajar. Pembelajaran yang menitikberatkan pada tercapainya penerapan literasi sains adalah pembelajaran yang sesuai dengan hakikat pembelajaran yang mana tidak hanya beriorentasi pada pengetahuan saja melainkan juga pada proses terintegrasinya konsep dan pengamalan serta ketercapaian dari sikap ilmiah. Oleh karena itu penerapan literasi sains juga harus diimbangi dengan pembelajaran inquiry ilmiah untuk menumbuhkan kemampuan berfikir kritis pada siswa agar mampu menyelesaikan segala persoalan yang ada sehingga siswa akan memperoleh pemahaman yang lebih mendalam terhadap alam sekitar.

Berdasarkan hasil observasi yang dilakukan peneliti pada beberapa Sekolah Dasar di Kota Baubau diketahui bahwa dalam pembelajaran IPA yang dilakukan oleh guru senantiasa menerapkan literasi sains 
dengan berbagai pendekatan, model, metode ataupun media yang digunakan berbasis literasi sains. Adapun pendekatan yang digunakan dalam mengimplementasikan literasi sains yaitu berupa pendekatan saintifik ataupun pendekatan kontekstual dan model pembelajaran tersebut salah satunya adalah pembelajaran berbasis masalah (PBM), pembelajaran berbasis masalah merupakan salah satu model pembelajaran yang beriorentasi pada siswa aktif. Mengingat begitu pesatnya perkembangan sains dan teknologi di era modern, dapat berdampak pada munculnya berbagai permasalah global sehingga peserta didik senantiasa harus dilatih dalam memecahan berbagai permesalahan yang bersifat autentik. Pada pembelajarn berbasis masalah, masalah dijadikan sebagai stimulus dan focus bagi aktivitas belajar siswa. Sehingga proses penerapan literasi sains akan melahirkan siswa yang mampu berfikir kritis.

Penerapan literasi sains di sekolah dasar sejalan dengan empat pilar pendidikan universal yang dirumuskan UNESCO yaitu learning to know, learning to do, learning to be dan learning to live. Pembelajran yang diharapkan di tingkat Sekolah Dasar adalah penekanan pada pembelajaran salingtemas (sains, lingkungan, teknologi dan masyarakat). Pembelajaran ini lebih diarahkan pada pengalaman belajar untuk merancang suatu karya melalui penerapan konsep IPA. Adapun untuk metode dan pendekatan yang digunakan dalam pembelajaran tidak dibatasi, artinya guru bebas menggunakan metode apapun dengan penekanan tujuan utama literasi sains tetap tercapai. Tujuan utama tersebut merupakan hasil pembelajaran interaksi guru dengan siswa, yaitu pengembangan dan penguasaan sikap ilmiah serta ketarampilan proses sains. Dapat dikatakan bahwa proses pembelajarannya menitikberatkan pada pemberian pengalaman langsung dan pengaplikasian hakikat sains. Meski metode pembelajaran tidak dibatasi, guru dianjurkan untuk menggunakan metode pembelajaran yang sesuai dengan pembelajaran sains seperti, problem based learning, project based learning, inquiry dan discovery learning. Jika dicermati, metode / model pembelajaran ini sesuai dengan model pembelajaran yang dianjurkan dalam kurikulum 2013. Sementara pemberian pengalaman langsung dan pengaplikasian sains diperoleh melalui pratikum. Pratikum merupakan suatu rangkaian kegiatan yang memungkinkan seorang siswa mengaplikasikan keterampilan atau mempraktikkan sesuatu (Daniah, 2020). Melalui pratikum diharapkan siswa tertarik untuk belajar, ikut serta dan tidak apatis. Setidaknya ada 3 faktor yang penting diperhatikan guru dalam menerapkan literasi sains di SD yaitu: 1. Stimulus siswa agar siap bealajar. 2. Libatkan siswa dalam pembelajaran. 3. Ciptakan suasana belajar yang menyengkan. Praktikum di atas termasuk salah satu cara menciptakan suasana belajar yang menyenangkan.

\section{Penilaian Literasi Sains}

Penilaian literasi sains yaitu menilai pemahaman peserta didik terhadap konten sains, proses sains, dan konteks aplikasi sains. Konten dalam literasi sains meliputi materi yang terdapat dalam kurikulum dan materi yang bersifat lintas kurikulum dengan penekanan pada pemahaman konsep dan kemampuan untuk menggunakannya dalam kehidupan. Proses sains merujuk pada proses mental yang terlibat ketika peserta didik memecahkan permasalahan. Sedangkan konteks adalah area aplikasi dari konsep-konsep sains. Sesuai dengan pandangan tersebut, penilaian literasi sains tidak semata-mata berupa pengukuran tingkat pemahaman terhadap pengetahuan sains tetapi juga pemahaman terhadap berbagai aspek proses sains serta kemampuan mengaplikasikan pengetahuan dan proses sains dalam situasi nyata yang dihadapi peserta didik, ini berarti bahwa penilaian literasi sains tidak hanya berorientasi pada penguasaan materi sains akan tetapi juga pada penguasaan kecakapan hidup, kemampuan berpikir dan kemampuan dalam melakukan proses-proses sains pada kehidupan nyata peserta didik.

\section{Media Pembelajaran Literasi sains Media}

Pembelajaran merupakan bagian yang tidak terpisahkan dalam menciptakan keefektifan proses pembelajaran. Media pembelajaran selayaknya dipilih sesuai dengan tujuan pembelajaran, materi ajar dan juga karakteristik peserta didik sebagai subjek belajar. Penggunaan media sebagai alat pendukung penguasaan kompetensi literasi sains dan kompetensi abad 21 dapat memainkan peranan pentingnya apabila dijadikan 
sebagai alat berpikir kritis dan digunakan dalam kegiatan inkuiri yang dilakukan oleh peserta didik. Apabila dilihat dari karakteristiknya siswa sekolah dasar pada umumnya berada pada tahap berpikir oprasional kongkrit, hal ini berdampak pada pemilihan media pembelajaran yang akan digunakan yang mana pada pembelajaran hendaknya media yang digunakan merupakan media konkrit yang dapat dioprasikan secara langsung sehingga konsep yang dipelajari dapat lebih mudah diterima dan difahami oleh peserta didik. Namun pemilihan media juga harus senantiasa didasarkan pada keterwakilan media tersebut dalam mengembangkan kemampuan berpikir kritis peserta didik.

\section{Kendala Penerapan Literasi Sains di Sekolah Dasar}

Penerapan kurikulum 2013 di Sekolah Dasar, Mata pelajaran IPA merupakan salah satu mata pelajaran wajib yang ada di tingkat sekolah dasar. Melalui IPA inilah mempunyai peranan penting untuk membekali peserta didik agar dapat diterapkan dalam kehidupan sehari-hari (Naila \& Khasna, 2021). Adapun faktor penghambat dalam penerapan literasi sains di sekolah dasar adalah kemampuan peserta didik dalam mengaplikasikan dalam kehidupan sehari-hari. Pengetahuan yang dimiliki sebatas teori dan berhenti pada bacaan saja. Selain itu faktor penghambat dalam gerakan literasi sains yaitu kurangnya dukungan beberapa orang tua peserta didik dan kurangnya minat baca peserta didik.

Saat ini pelaksanaan Gerakal Literasi Sekolah (GLS) di jenjang pendidikan sudah mulai digalakkan. Faktor pendukung dalam gerakan literasi sains yaitu SDM (guru kelas, orang tua peserta didik, kepala sekolah, dan warga sekolah). Guru sebagai ujung tombak dalam pelaksanaan literasi dituntut mampu melaksanakan tugas dan perannya dengan maksimal (Astini, 2019). Fasilitas yang tersedia di sekolah (perputakaan sekolah, referensi buku bacaan di sekolah, dan pojok baca). Berdasarkan data penelitian juga menunjukkan perpusatakaan merupakan salah satu pendukung utama untuk melaksanakan literasi. Literasi sains mempunyai peranan penting dalam IPTEK. Literasi sains dianggap sebagai salah satu ujuan utama dalam pendidikan sains. Untuk itu proses pembelajaran IPA yang termuat dalam tema di kurikulum 2013 ini harus memuat literasi sains. Karena usia di SD peserta didik mempunyai rasa skeptis/ rasa ingin tahun tinggu maka perlu diwadahi dengan literasi sains, sehingga dapat melakukan ujicoba sederhana.

Sedangkan hasil wawancara dengan guru di Sekolah Dasar di Kota Baubau memperoleh beberapa informasi mengenai kegiatan literasi sains. Referensi buku untuk kegiatan literasi peserta didik di kelas sudah banyak, terlebih buku untuk literasi sains. Buku yang tersedia untuk literasi sudah disediakan oleh sekolah, terkadang orang tua peserta didik juga ikut membantu atau menyumbangkan buku, biasanya peserta didik juga membawa buku sendiri. Peserta didik pada kelas IV membaca banyak referensi buku, seperti buku cerita, ensiklopedia, buku komik, dan majalah anak-anak. Peserta didik sangat bersemangat membaca terlebih membaca cerita atau ensiklopedia tentang sains. Peserta didik juga saling meminjamkan buku kepada teman satu kelas agar satu kelas dapat membaca buku yang sama.

\section{KESIMPULAN}

Kegiatan pembelajaran IPA di Sekolah Dasar saat ini menekankan proses pembelajaran berpusat pada peserta didik yang dapat dikembangkan melalui implementasi pembelajaran literasi sains. Dalam hal ini keberhasilan pembelajaran ditunjukkan apabila peserta didik memahami apa yang dipelajari serta dapat mengaplikasikannya dalam menyelesaikan berbagai masalah dalam kehidupan sehari- hari. Oleh karena itu, pembelajaran literasi sains penting bagi peserta didik untuk memahami apa yang dipelajari. Literasi sains dapat dijadikan acuan sebagai pengembangan pembelajaran IPA karena literasi sains dinilai efektif dalam mengembangkan pembelajaran IPA.

Implementasi literasi sains dapat mengembangkan pola pikir dan prilaku siswa serta membangun karakter manusia untuk peduli, bertanggungjawab terhadap dirinya, masyarakat, alam semesta serta terhadap masalah yang dihadapi masyarakat modern saat ini. Siswa yang mampu mengembangkan literasi sains dapat 
membuat keputusan yang mendasar dan mampu mengenali sumber solusi yaitu sains dan teknologi. Literasi sains juga memiliki peranan yang penting untuk membangun kesejahteraan masyarakat dimasa sekarang maupun masa yang akan datang.

\section{UCAPAN TERIMA KASIH}

Penulis mengucapkan terima kasih yang sebesar-besarnya kepada Bapak/ibu guru di Sekolah Dasar Kota Baubau sebagai responden dalam penelitian ini dan pihak-pihak yang sudah membantu dalam menyelesaikan penelitian ini, juga kepada pihak jurnal Edukatif yang telah membantu dalam mempublish artikel.

\section{DAFTAR PUSTAKA}

Asrizal, A., Festiyed, F., \& Sumarmin, R. (2017). Analisis Kebutuhan Pengembangan Bahan Ajar Ipa Terpadu Bermuatan Literasi Era Digital Untuk Pembelajaran Siswa Smp Kelas Viii. Jurnal Eksakta Pendidikan (Jep), 1(1), 1. Https://Doi.Org/10.24036/Jep/Vol1-Iss1/27

Astini, N. K. S. (2019). Pentingnya Literasi Teknologi Informasi Dan Komunikasi Bagi Guru Sekolah Dasar Untuk Menyiapkan Generasi Milenial. Prosiding Seminar Nasional Dharma Acarya, 1(2018), 113-120.

Basam, F., Rusilowati, A., \& Ridlo, S. (2016). Pancasakti Science Education Journal. Formulasi Minyak Atsiri Daun Jeruk Purut (Citrus Hystrix D.C.) Sebagai Sediaan Aromaterapi, 7(1), 1-8.

Cahyani, D., \& Roviati, E. (2016). Penerapan Pembelajaran Ipa Berbasis Keterampilan Proses Sains Untuk Meningkatkan Literasi Sains Pada Mata Pelajaran Ipa Di Kelas Vii Materi Pokok Pencemaran Lingkungan Di Smpn 1 Cikijing. Jurnal Sains Dan Pendidikan Sainspd.I; Jurusan Tadris Ipa Biologi Jalan Perjuangan Bypass Sunyaragi Cirebon, 5(45132), 122-135. Www.Syekhnurjati.Ac.Di/Jurnal/Index.Php/Sceducatia

Daniah, D. (2020). Pentingnya Inkuiri Ilmiah Pada Praktikum Dalam Pembelajaran Ipa Untuk Peningkatan Literasi Sains Mahasiswa. Pionir: Jurnal Pendidikan, 9(1), 144-153. Https://Doi.Org/10.22373/Pjp.V9i1.7178

Fadillah, E. N. (2017). Development Of Assessment Instruments To Measure The Science Process Skills Of High School Students. Didaktika Biologi, 1(2), 123-134. Http://Jurnal.UmPalembang.Ac.Id/Dikbio/Article/View/770/701

Fitariya, F. (2018). Meningkatkan Literasi Sains Di Sdn Sidokumpul Dengan Metode Exsperimen. Ptk A3 Pgsd Fkip Universitas Muhammadiyah .... Http://Eprints.Umsida.Ac.Id/3048/

Handayani*, N. A., \& Jumadi, J. (2021). Analisis Pembelajaran Ipa Secara Daring Pada Masa Pandemi Covid-19. Jurnal Pendidikan Sains Indonesia, 9(2), 217-233. Https://Doi.Org/10.24815/Jpsi.V9i2.19033

Kristyowati, R., \& Purwanto, A. (2019). Pembelajaran Literasi Sains Melalui Pemanfaatan Lingkungan. Scholaria: Jurnal Pendidikan Dan Kebudayaan, 9(2), 183-191. Https://Doi.Org/10.24246/J.Js.2019.V9.I2.P183-191

Naila, I., \& Khasna, F. T. (2021). Pengaruh Pembelajaran Daring Terhadap Kemampuan Literasi Sains Calon Guru Sekolah Dasar: Sebuah Studi Pendahuluan. ... Dasar: Jurnal Kajian Pendidikan Dan Hasil ..., 7(1), 42-47. Https://Journal.Unesa.Ac.Id/Index.Php/Pd/Article/View/12177

Narut, Y. F., \& Supradi, K. (2019). Literasi Sains Peserta Didik Dalam Pembelajaran Ipa Di Indonesia. Jurnal Inovasi Pendidikan Dasar, 3(1), 61-69.

Pertiwi, U. D., Atanti, R. D., \& Ismawati, R. (2018). Pentingnya Literasi Sains Pada Pembelajaran Ipa Smp Abad 21. Indonesian Journal of Natural Science Education (Ijnse), 1(1), 24-29. Https://Doi.Org/10.31002/Nse.V1i1.173 
5639 Implemensi Literasi Sains dalam Pembelajaran IPA di Sekolah Dasar - Irsan DOI: https://doi.org/10.31004/basicedu.v5i6.1682

Rizkita, L., Suwono, H., \& Susilo, H. (2016). Pengaruh Pembelajaran Socio-Scientific Problem-Based Learning Terhadap Keterampilan Metakognitif Dan Hasil Belajar Kognitif Siswa Kelas X Sman Kota Malang. 2017, 1(4), 732-738.

Rustaman, N. Y. (2017). Mewujudkan Sistem Pembelajaran Sains / Biologi Berorientasi Pengembangan Literasi Peserta Didik Rustaman, Mewujudkan Sistem Pembelajaran Rustaman, Mewujudkan Sistem Pembelajaran Ks-2. April, 1-8.

Setiawan, A. R. (2019). Efektivitas Pembelajaran Biologi Berorientasi Literasi Saintifik. Thabiea : Journal Of Natural Science Teaching, 2(2), 83-94. Https://Doi.Org/10.21043/Thabiea.V2i2.5345

Syofyan, H., \& Amir, T. L. (2019). Penerapan Literasi Sains Dalam Pembelajaran Ipa Untuk Calon Guru Sd. Journal Pendidikan Dasar, 10(2), 35-43.

Van Noordwijk, M. (2021). Agroforestry-Based Ecosystem Services: Reconciling Values Of Humans And Nature In Sustainable Development. Land, 10(7). Https://Doi.Org/10.3390/Land10070699

Zuriyani, E. (2021). Implementasi Pelatihan E-Learning Era Pandemik. Jurnal Perspektif, 14(1), 138-160. Https://Doi.Org/10.53746/Perspektif.V14i1.42 